\title{
Efektivitas Teh Kompos Berbahan Dasar Berbeda pada Pertumbuhan dan Produksi Rumput Benggala (Panicum maximum)
}

\author{
Dedi Tahoni ${ }^{\mathrm{a}}$, Oktovianus R. Nahak ${ }^{\mathrm{b}}$, Polikarpia W. Bani \\ ${ }^{a}$ Fakultas Pertanian, Universitas Timor, Kefamenanu, TTU - NTT, Indonesia, email: deditahoni@gmail.com
${ }^{b}$ Fakultas Pertanian, Universitas Timor, Kefamenanu, TTU - NTT, Indonesia, email:oktovianusrafael@yahoo.co.id
${ }^{c}$ Fakultas Pertanian, Universitas Timor, Kefamenanu, TTU - NTT, Indonesia, email:helmi_bani@yahoo.com
}

Article Info

\section{Article history:}

Received 10 Juni 2019

Received in revised form 15 Juni 2019 Accepted 15 Juli 2019

https://doi.org/10.32938/ja.v4i3.715

\section{Keywords:}

Rumput Benggala (Panicum maximum) Teh Kompos

Pupuk Guano

Ekskreta Ayam

Feses Sapi

\begin{abstract}
Abstrak
Penelitian ini dilaksanakan pada kebun percobaan milik Fakultas Pertanian Universitas Timor, Kelurahan Sasi, Kecamatan Kota Kefamenanu, Kabupaten Timor Tengah Utara selama satu periode penanaman (45) hari Terhitung Bulan November 2018 Sampai Bulan Januari 2019. Tujuan dari penelitian ini untuk mengetahui efektivitas teh kompos berbahan dasar berbeda terhadap pertumbuhan dan produksi rumput Benggala (Panicum maximum). Penelitian ini menggunakan metode eksperimen, menggunakan rancangan acak lengkap (RAL) dengan 4 perlakuan 4 ulangan. Adapun perlakuan yang diuji adalah sebagai berikut : R0 : Tanpa Teh Kompos. R1 : Teh Kompos Berbahan Dasar Guano. R2 : Teh Kompos Berbahan Dasar Feses Sapi. R3 : Teh Kompos Berbahan Dasar Ekskreta Ayam. Variabel yang diamati berupa: tinggi tanaman, jumlah daun, jumlah anakan, berat segar tanaman, berat kering tanaman. Hasil penelitian menunjukkan bahwa perlakuan teh kompos berbahan dasar berbeda menghasilkan tinggi tanaman terbaik pada perlakuan penggunaan teh kompos berbahan dasar ekskreta ayam yaitu pada perlakuan R3 sebesar 108, $12 \mathrm{~cm}$, jumlah anakan terbanyak pada perlakuan R3 dengan bahan dasar ekskreta ayam sebanyak 3,85 anakan, jumlah daun terbanyak pada perlakuan R3 dengan teh kompos berbahan dasar ekskreta ayam sebanyak 7,21 helai daun, berat kering terendah pada perlakuan R3 dengan teh kompos berbahan dasar exkreta ayam sebanyak 190, $499 \%$, berat segar tertinggi pada perlakuan R3 dengan teh kompos bahan dasar ekskreta ayam sebanyak 950,00 g. Namun secara statistik menunjukan bahwa pemberian perlakuan teh kompos berbahan dasar berbeda pada level yang sama menghasilkan pertumbuhan dan produksi yang sama atau berbeda tidak nyata untuk semua variabel pengamatan. Disimpulkan bahwa pemberian teh kompos berbahan dasar pupuk guano, feses sapi dan ekskreta ayam menghasilkan nilai pertumbuhan dan produksi yang sama hal ini karena unsur hara yang tersedia dalam teh kompos yang diberikan relatif sama.
\end{abstract}

\section{Pendahuluan}

Hijauan merupakan sumber pakan ternak yang utama dan sangat besar peranannya bagi ternak ruminansia (sapi, kerbau, kambing dan domba) baik untuk pertumbuhan, produksi (daging dan susu) maupun reproduksi. Dalam mengembangkan usaha ternak ruminansia,penyediaan hijauan sangat penting untuk diperhatikan karena ketersediaan hijauan pakan yang cukup (kuantitas, kualitas dan kontinuitas) merupakan faktor yang menentukan keberhasilan usaha peternakan. Salah satu jenis hijauan yang umum digunakan sebagai pakan ternak adalah rumput benggala (Panicum maximum). Rumput benggala merupakan salah satu jenis rumput yang memiliki kualitas baik, disamping itu rumput benggala (Panicum maximum) termasuk tanaman pakan berumur panjang, dapat beradaptasi pada semua jenis tanah, tahan terhadap naungan dan palatable (disukai ternak). Aganga dan Tshwenyane (2004) menyatakan bahwa rumput benggala mengandung protein sebesar 5,0\% sampai 5,6\%. Tingg tanaman rumput benggala mencapai 1,00-1,50 m. Daun bentuk pita yang sangat banyak jumlahnya itu terbangun garis, berwarna hijau, panjang 40-105 cm dengan lebar 10-30 mm, tegak, bercabang-cabang, sering kali diselaput lapisan lilin putih (Sajimin et al., 2004)

Saat ini ketersediaan hijauan makanan ternak khususnya rumput benggala semakin menurun dikerenakan belum ada perhatian khusus dalam proses pengembangannya sehingga ketersediaan hijauan makanan ternak menjadi sangat terbatas, disamping itu produktivitas dan kualitasnya semakin menurun. Hal ini terjadi karena menurunnya kualitas tanah (degradasi lahan) yang disebabkan oleh kehadiran bahan-bahan pencemar ditanah. Selain itu penggunaan pupuk kimia secara terus-menerus dalam jumlah banyak merupakan salah satu penyebab degradasi lahan (Kartini, 2000). Kondisi tersebut dapat ditanggulangi dengan usaha mengembalikan unsur-unsur hara kedalam tanah. Salah satu usaha yang dilakukan adalah dengan car pemupukan, yang pada dasarnya, dimaksudkan untuk mencukupi kebutuhan hara dalam tanah agarbpotensi genetik tanaman dapat dikembangkan secara maksimal. Dengan pemupukan kesuburan lahan dapat dipertahankan atau bahkan dapat ditingkatkan sehingga dapat meningkatkan produktivitas dari tanaman rumput yang dibudidayakan. Untuk memperoleh produksi yang tinggi pada lahan yang tingkat kesuburannya rendah dapat dilakukan dengan penggunaan pupuk organik (Sajimin et al., 2001).

Salah satu pupuk organik yang berperan dalam memperbaiki sifat fisik, kimia dan biologis tanah serta lingkungan adalah pupuk organik berbentuk teh kompos. Teh kompos adalah cairan yang berasal dari leaching kompos yang kaya dengan nutrisi dan populasi mikroba (bakteri, jamur, protozoa, nematode) yang bermanfaat bagi tanaman. Teh kompos bermanfaat untuk meningkatkan tekanan terhadap penyakit atau ketahanan terhadap serangan patogen, menyuplai hara terlarut bagi tanaman, meningkatkan populasi, diversitas dan aktivitas mikroorganisme tanah yang berperan dalam perbaikan struktur tanah, retensi air, penetrasi akar dan pertumbuhan tanaman (Recycled Organics Unit, 2006). Wiryanta dan Bernardinus, (2002) menyatakan bahwa pupuk kandang ayam mengandung unsur N 3,21\%, P 3,21\%, K 1,57\%, Ca 1,57\%, Mg 1,44 $\%$, Mn 250 ppm, Zn 315 ppm. Kandungan pupuk kandang kotoran sapi yaitu $25 \%$ nitrogen (n), 7\% fosfor (p) , 9\% kalium (k) 3,7\% zat besi (fe), dan unsur hara lain (Prasetya, 2014). Pupuk guano dapat memperbaiki kesuburan tanah, pupuk guano mengandung 7-17 \% N, 8-15\% P, dan 1,5-2,5\% K, (Suwarno dan Idris, 2007). Penelitian ini menggunakan teh kompos yang berbahan dasar ekskreta ayam, feses sapi dan pupuk guano untuk melihat pertumbuhan dan produksi rumput benggala (Panicum maximum).

\section{Metode}

\subsection{Waktu dan Lokasi Penelitian}

Penelitian ini dilaksanakan pada kebun percobaan milik Fakultas Pertanian Universitas Timor, Kelurahan Sasi, Kecamatan Kota Kefamenanu, Kabupaten Timor Tengah Utara selama satu masa produksi (45 hari). Terhitung dari bulan November tahun 2018 sampai bulan Januari tahun 2019.

\subsection{Alat dan bahan}

Alat-alat yang digunakan dalam penelitian ini antara lain alat ukur seperti : penggaris, timbangan, termometer alat pembuatan teh kompos seperti: Aerator (pompa air), ember, kain kasa, terpal serta alat pertanian seperti Linggis, skop, pacul, parang, gembor, tengki semprot, oven, kertas amflop. Bahan yang digunakan adalah : Teh kompos berbahan dasar pupuk guano, feses sapi, ekskreta ayam dan pols rumput benggala, gula pasir serta EM4.

\subsection{Rancangan Percobaan}

Metode yang digunakan dalam penelitian ini adalah metode eksperimen mengunakan rancangan acak Lengkap (RAL) dengan 4 perlakuan 4 ulangan sehinggaterdapat 16 unit satuan percobaan. Adapun perlakuan yang ujiadalah:

R0 : Tanpa Teh Kompos,

R1 : Teh Kompos Berbahan Dasar Guano,

R2 : Teh Kompos Berbahan Dasar Feses Sapi,

R3 : Teh Kompos Berbahan Dasar Ekskreta Ayam.

Penelitian diawali dengan pembersihan lahan yang dipakai dan dibuat dalam bentuk teras dan dibagi dalam 16 buah unit satuan percobaan dengan ukuran tiap unit $2 \times 1,5 \mathrm{~m}$ yang terbagi dalam 4 blok dengan jarak antara unit dan blok $50 \mathrm{~cm}$ sehingga total luaslahan yang dibutuhkan $100 \mathrm{~m}^{2}$. Dalam tiap unit satuanpercobaan terdapat sembilan (9) lubang tanaman yang ditanam dua (2) buah pols rumput benggala. Jenis pupuk yang digunakan adalah teh kompos. Teh kompos yang diberikan di setiap tanaman sebanyak $500 \mathrm{ml}$ pada setiap lubang tanam sehingga teh kompos yang dibutuhkan sebanyak 576 liter untuk ketiga jenis teh kompos. Perlakuan dilakukan dengan cara disemprot ke setiap tanaman dan dilakukan lima hari sekali.

\subsection{ProsedurPenelitian}

\subsubsection{Pembuatan kompos}

Kebutuhan dan pembuatan kompos yang berbahan dasar guano, feses sapi dan ekskreta ayam (kebutuhan untuk $50 \mathrm{~kg}$ bahan dasar). Bahan :

- Pupuk, guano/sapi/ekskreta ayam : $50 \mathrm{~kg}$

- Daun gamal : $15 \mathrm{~kg}$

- Daun lamtoro $\quad: 15 \mathrm{~kg}$

- Bunga putih $\quad: 15 \mathrm{~kg}$

- Dedak padi $\quad: 4 \mathrm{~kg}$

- EM-4 $\quad: 500 \mathrm{ml}$

- Gula pasir $\quad: 500 \mathrm{~g}$

- Air bersih

301

\subsubsection{BahanPembuatantehkompos} kompos:

Pembutan teh kompos untuk kebutuhan 20 liter air pada setiap jenis teh

- Kompos : $: 2 \mathrm{~kg}$

- Gula pasir : $500 \mathrm{~g}$

- EM4 : 6 tutupan botol EM4

- Air bersih : $20 \mathrm{~L}$ 


\subsubsection{Cara pembuatan Pembuatan kompos:}

- Pupuk guano, feses sapi, ekskreta ayam yang sudah dihaluskan dicampurkan dengan daun gamal, daun lamtoro dan semak bunga putih serta dedak padi sampai homogen

- Gula pasir dan EM4 dilarutkan dengan air kemudian dipercikkan ke campuran bahan-bahan yang sudah dicampur sebelumnya.

- Kemudian ditutup (proses fermentasi) menggunakan terpal selama 14 hari dan dilakukan pembalikan setiap 3 hari sekali agar suhu tidak lebih dari $50^{\circ} \mathrm{C}$

\subsubsection{Cara Pembuatan teh kompos}

- Air disiapkan sebanyak 20 liter diwadah atau tempat penampung kemudian kompos yang dibungkus dengan kain sebanyak $2 \mathrm{~kg}$ dimasukan kedalam air, kemudian tambahkan gula pasir sebanyak 500 g dan EM4 6 tutupan botol disetiap jenis teh kompos.

- Proses fermentasinya dibantu dengan alat pompa air (aerator).

- Proses fermentasi dibiarkan selama 24 jam.

2.4.5 Penanaman Bibit

Penanaman pols atau rumput benggala pada tiap lubang diisi 2 buah pols rumput benggala dengan kedalaman lubang $\pm 10 \mathrm{~cm}$ selanjutnya dipadatkan dengan tanah. Tiap pols rumput benggala dipotong dengan ukuran $15 \mathrm{~cm}$ untuk menciptakan keseragaman. Penanaman pols dilakukan dengan jarak tanam $60 \mathrm{x}$ $80 \mathrm{~cm}$.

\subsubsection{Pemberian Pupuk}

Setelah pembuatan bedeng dilanjutkan dengan pembuatan lubang tanam. Pemberian pupuk berupa teh kompos diberikan setelah proses penanaman dengan cara disemprot pada setiap tanaman sebanyak $500 \mathrm{ml}$ pada setiap lubang tanaman.

\subsubsection{Pemeliharaan Tanaman}

Pemeliharaan tanaman meliputi penyiraman, pemberantasan gulma. Penyiraman dilakukan 2 kali sehari pada pagi hari dan sore hari.Sedangkan untuk pembersihan gulma dilakukan setiap 1 minggu sekali dan penggemburan dilakukan apabila tanah pada bedeng terlihat padat.

\subsubsection{Pengambilan Data}

Data di peroleh dengan cara pengukuran yang dilakukan setiap 15 hari sekali untuk tinggi tanaman, jumlah daun disetiap anakan, jumlah anakan dan untuk berat segar tanaman pengambilan datanya disaat rumput benggala berusia 45 hari setelah tanam, dengan cara penimbangan pada setiap petak, sementara untuk barat kering diperoleh datanya setelah rumput melewati proses pengeringan oven pada suhu $70^{\circ} \mathrm{C}$ selama 48 jam.

\subsection{Variabel Penelitian}

\subsubsection{Tinggi Tanaman}

Tinggi tanaman diukur dari titik tumbuh hingga ujung daun yang paling tertinggi dengan menggunakan meter. Tinggi tanaman diukur satu minggu setelah trimming/pemangkasan kemudian dilakukan perhitungan rataan tinggi tanaman.

$\mathrm{TT}=\frac{\mathrm{TT} 1+\mathrm{TT} 2+\mathrm{TT} 3}{\mathrm{~T}}$

Keterangan :

TT1 = Tinggi tanaman penggukuran pertama

TT2 = Tinggi tanaman penggukuran kedua

TT3 = Tinggi tanaman penggukuran ketiga

$\mathrm{T}=$ Waktu (hari).

\subsubsection{Jumlah daun}

Jumlah daun dihitung dan mengamati banyaknya daun yang baru tumbuh pada pols tanaman.

JD $=\frac{\text { JD1 + JD2 + JD3 }}{T}$

TT1 = Jumlah daun penggukuran pertama

TT2 = Jumlah daun penggukuran kedua

TT3 = Jumlah daun penggukuran ketiga

$\mathrm{T}=$ Waktu (hari).

\subsubsection{Jumlah Anakan}

Jumlah anakan diukur dengan cara menghitung setiap anakan yang tumbuh setiap minggunya kemudian dilakukan perhitungan rataan jumlah anakan.

$\mathrm{JA}=\frac{\mathrm{JA} 1+\mathrm{JA} 2+\mathrm{JA} 3}{\mathrm{~T}}$

Keterangan :

JA1 = Jumlah anakan penggukuran pertama.

JA2 = Jumlah anakan penggukuran kedua

JA3 = Jumlah anakan penggukuran ketiga

$\mathrm{T}=$ Waktu (minggu).

\subsubsection{Berat Segar Tanaman}

Berat segar tanaman diukur dengan cara penimbangan pada masa produksi pertama 45 hari setelah tanam :

$\mathrm{BSD}=\frac{\mathrm{BSD} 1+\mathrm{BSD} 2+\mathrm{BSD}}{\mathrm{T}}$

Keterangan :
BSD1 = berat segar tanaman penggukuran pertama.

BSD2 = berat segar tanaman penggukuran kedua

BSD3 = berat segar tanaman penggukuran ketiga

$\mathrm{T}=$ Waktu (minggu).

\subsubsection{Berat Kering Tanaman}

Berat kering diukur dengan cara penimbangan pada rumput yang sudah dikeringkan di dalam oven selama 48 jam pada suhu $70^{\circ} \mathrm{C}$.

$\mathrm{BKD}=\frac{\mathrm{BKD} 1+\mathrm{BKD} 2+\mathrm{BKD} 3}{\mathrm{~T}}$

Keterangan :

BKD1 = Berar Kering tanaman penggukuran pertama.

$\mathrm{BKD} 2=$ Berar Kering tanaman penggukuran kedua

BKD3 = Berar Kering tanaman penggukuran ketiga

$\mathrm{T} \quad=$ Waktu (minggu).

\subsection{Analisis Data}

Data pengamatan dianalisis menggunakan sidik ragam (Anova) sesuai Rancangan Acak Lengkap (RAL) Selanjutnya diuji lanjut menggunakan Duncan Multiple Range Test (DMRT) dengan tingkat signifikan $0.05 \%$. Analisis data menggunakan software SAS versi 9.1.

\section{Hasil dan Pembahasan}

\subsection{Tinggi Tanaman}

Tinggi tanaman merupakan salah satu kriteria dalam mengetahui laju pertumbuhan tanaman. Tinggi tanaman hasil penelitian dapat dilihat pada Gambar 1.

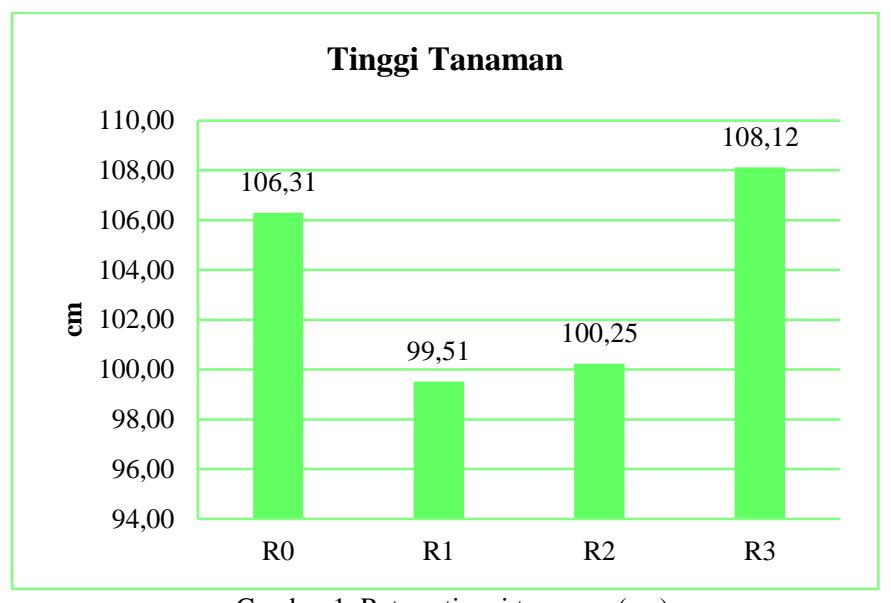

Gambar 1. Rataan tinggi tanaman $(\mathrm{cm})$

Data pada Gambar 1 menunjukkan bahwa tinggi tanaman rumput benggala dihasilkan pada perlakuan pemberian teh kompos berbahan dasar ekskreta ayam (R3) yang menghasilkan tinggi tanaman $108,12 \mathrm{~cm}$ sedangkana tanaman yang paling rendah ditunjukan pada perlakuan teh kompos guano (R1) dengan tinggi tanaman $99,51 \mathrm{~cm}$

Hasil analisis sidik ragam (Anova) menunjukan bahwa pemberian teh kompos berbahan dasar berbeda terhadap tinggi tanaman rumput benggala secara statistik menunjukkan berpengaruh tidak nyata. Namun demikian tinggi tanaman terbaik dalam penelitian ini dihasilkan pada perlakuan R3, dimana perubahan tinggi tanaman sangat dipenguruhi oleh ketersediaan unsur hara pada teh kompos yang digunakan. Unsur hara yang paling berperan pada tinggi tanaman adalah nitrogen (N). Hal ini sesuai pendapat Purbajanti (2013) bahwa unsur nitrogen diperlukan untuk pembentukan atau pertumbuhan bagian vegetatif tanaman, seperti daun, batang dan akar. Nitrogen juga berperan penting dalam hal pembentukan hijau daun yang berguna dalam proses fotosintesis. Unsur $\mathrm{N}$ berperan untuk mempercepat fase vegetatif karena fungsi utama unsur $\mathrm{N}$ itu sendiri sebagai sintesis klorofil. Klorofil berfungsi untuk menangkap cahaya matahari yang akan dimanfaatkan dalam pembentukan makanan pada proses fotosintesis, kandungan klorofil yang cukup dapat membentu atau memacu pertumbuhan tanaman terutama merangsang organ vegetatif tanaman. Pertumbuhan akar, batang, dan daun terjadi dengan cepat jika persediaan makanan yang digunakan untuk proses pembentukan organ tersebut dalam keadaan atau jumlah yang cukup. Hasil analisis kandungan teh kompos ekskreta ayam menunjukkan kandungan $\mathrm{N}$ sebanyak $1,33 \%$ yang lebih tinggi dibandingkan teh kompos guano $\mathrm{N} 1,30 \%$ dan sapi kandungan $\mathrm{N}$ sebanyak $1,12 \%$.

\subsection{Jumlah Daun}

Jumlah daun merupakan salah satu kriteria dalam mengetahui daun yang dihasilkan tanamnan selama pertumbuhan. Jumlah daun dapat dilihat pada Gambar 2.

Data pada Gambar 2 menunjukkan bahwa jumlah daun rumput benggala secara statistik menunjukkan bahwa jumlah daun terbaik pada perlakuan $\mathrm{R}_{3}$ (7,21 helai) dengan penggunaan teh kompos berbahan dasar ekskreta ayam sedangkan paling rendah pada perlakuan R0 sebanyak 6,76. Analisis sidik 
ragam (Anova) terhadap jumlah daun menunjukkan bahwa pemberian perlakuan teh kompos berbahan dasar berbeda pada level yang sama menghasilkan jumlah daun yang tidak berbeda nyata. Namun demikian jumlah daun terbaik dalam penelitian ini dihasilkan pada perlakuan R3, dimana perubahan jumlah daun sangat dipanguruhi oleh ketersediaan unsur hara pada teh kompos yang digunakan. Unsur hara yang paling berperan pada jumlah daun adalah nitrogen (N). Menurut Hasibuan (2006), nitrogen mendorong pertumbuhan organ-organ yang berperan dalam fotosintesis seperti daun. Hasil analisis kandungan teh kompos ekskreta ayam menunjukkan kandungan $\mathrm{N}$ sebanyak 1,33\% yang lebih tinggi dibandingkan teh kompos guano $\mathrm{N} \mathrm{1,30 \%}$ dan sapi kandungan $\mathrm{N}$ sebanyak $1,12 \%$.

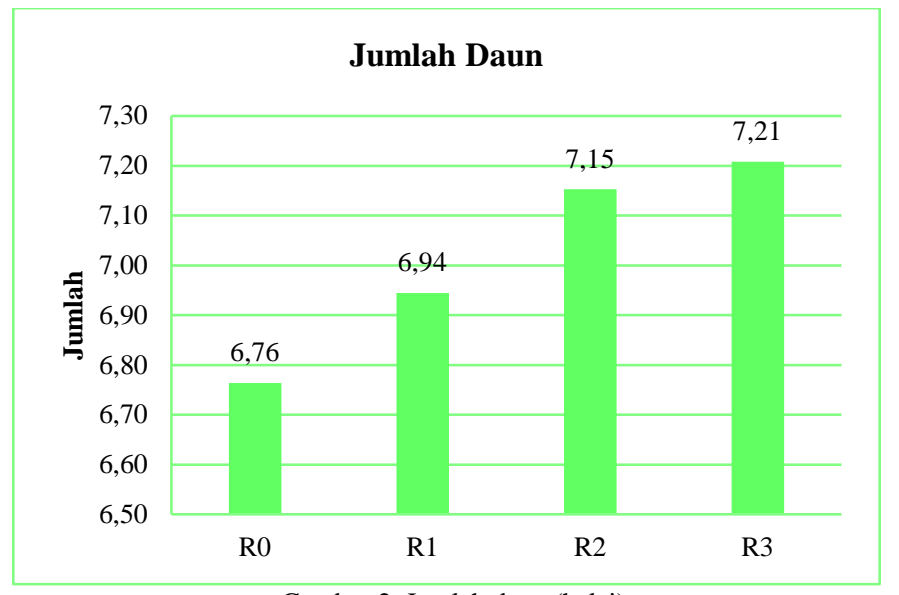

Gambar 2. Jumlah daun (helai)

\subsection{Jumlah Anakan}

Jumlah anakan merupakan salah satu kriteria dalam mengetahui peningkatan tanaman menghasilkan anakan baru selama pertumbuhan. Jumlah anakan dapat dilihat pada Gambar 3.

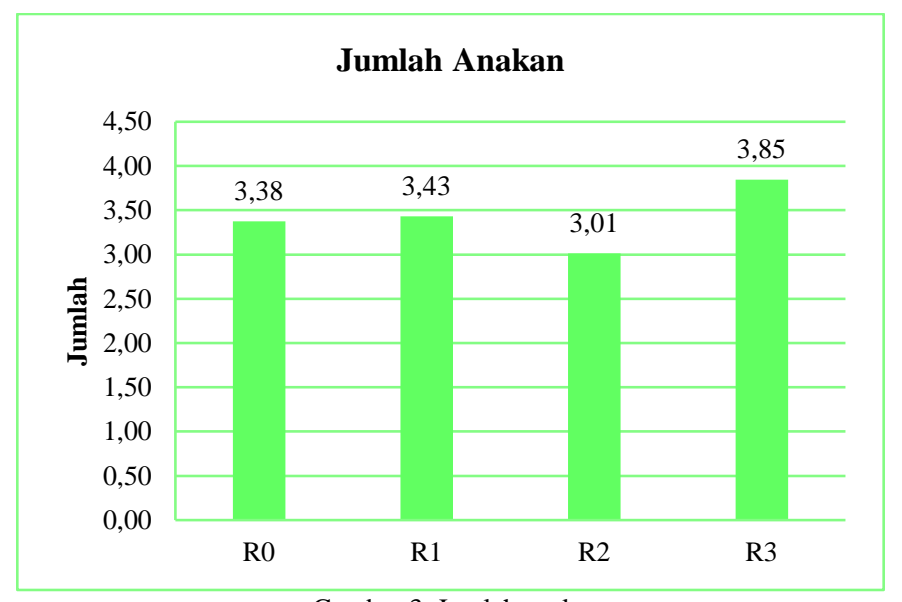

Gambar 3. Jumlah anakan

Data pada Gambar 3 menunjukkan bahwa jumlah anakan rumput benggala yang diberi perlakuan teh kompos berbahan dasar pupuk guano, feses sapi dan ekskreta ayam pada level $500 \mathrm{ml}$ menghasilkan jumlah anakan yang relatif sama.Tiap perlakuan cenderung menghasilkan perbedaan karakter pada jumlah anakan yang dihasilkan. Secara statistik menunjukkan bahwa jumlah anakan tertinggi pada perlakuan R3 $(3,85)$ dan terendah pada perlakuan R2 sebanyak 3,01. Analisis sidik ragam terhadap jumlah anakan menunjukkan bahwa pemberian perlakuan teh kompos berbahan dasar berbeda pada level yang sama menghasilkan jumlah anakan yang berbeda tidak nyata. Namun demikian jumlah anakan terbaik dalam penelitian ini dihasilkan pada perlakuan R3, dimana perubahan jumlah anakan sangat dipanguruhi oleh ketersediaan unsur hara yang disediakan oleh teh kompos yang digunakan. Prasetya et al.,(2009) menjelaskan bahwa peningkatan serapan $\mathrm{N}$ tanaman akan diikuti oleh peningkatan pertumbuhan tanaman yang meliputi tinggi tanaman, jumlah daun, bobot segar, bobot kering tanaman, jumlah anakan dan kadar $\mathrm{N}$ tanaman. Pertumbuhan akar, batang, daun dan anakan terjadi dengan cepat jika persediaan makanan yang digunakan untuk proses pembentukan organ tersebut dalam keadaan atau jumlah yang cukup.

\subsection{Berat Segar Dan Kering Tanaman}

Berat segar dan kering tanaman merupakan salah satu parameter yang dapat mewakili pertumbuhan tanaman. Semakin besar berat segar dan kering tanaman berarti semakin banyak biomasa yang dihasilkan. Berat segar dan kering tanaman hasil penelitian dapat dilihat pada Gambar 4.

Data pada Gambar 4 menunjukkan bahwa berat segar dan kering rumput benggala yang diberi perlakuan teh kompos berbahan dasar pupuk guano, feses sapi dan ekskreta ayam pada level $500 \mathrm{ml}$ menghasilkan berat segar dan kering yang relatif sama. Tiap perlakuan cenderung menghasilkan perbedaan karakter pada berat segar dan kering tanaman yang dihasilkan. Secara statistik menunjukkan bahwa berat segar tanaman tertinggi ditunjukkan pada perlakuan R3 $(950,00 \mathrm{~g})$ dan berat kering tanaman tertinggi ditunjukkan pada perlakuan R3 $(190,49 \mathrm{~g})$ dan berat segar terendah pada perlakuan R2 sebanyak 750,00\% sementara berat kering terendah pada perlakuan R2 sebanyak 135,52\%. Analisis sidik ragam terhadap berat segar dan kering tanaman menunjukkan bahwa pemberian perlakuan teh kompos berbahan dasar berbeda pada level yang sama menghasilkan berat segar dan kering tanaman yang tidak berbeda nyata. Ferguson et al., (2010)menyatakan bahwa unsur N diperlukan untuk pembentukan atau pertumbuhan bagian vegetatif tanaman, seperti daun, batang dan akar. Pertumbuhan akar, batang, dan daun terjadi dengan cepat jika persediaan makanan yang digunakan untuk proses pembentukan organ tersebut dalam keadaan atau jumlah yang cukup.

\section{Berat Segar Dan Kering Tanaman}

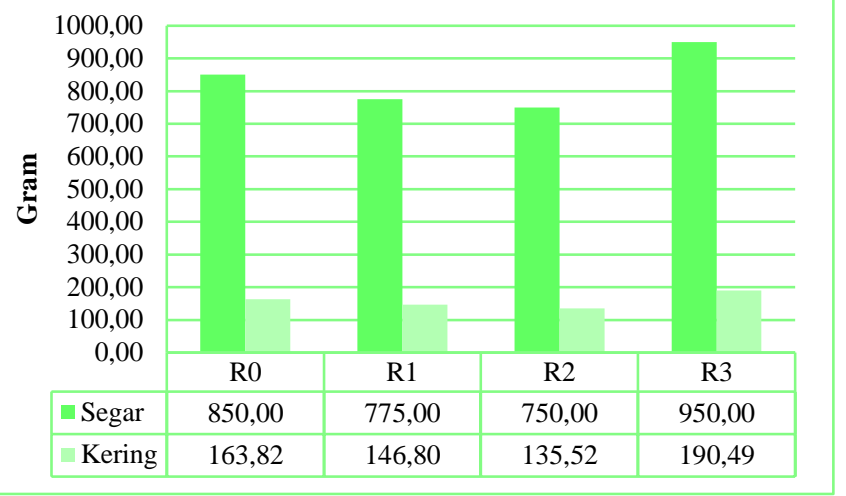

Gambar 4. Berat segar dan kering tanaman (g)

\section{Simpulan}

Disimpulkan bahwa pemberian teh kompos berbahan dasar pupuk guano, feses sapi dan ekskreta ayam menghasilkan nilai pertumbuhan dan produksi yang sama yang disebabkan karena unsur hara yang tersedia dalam teh kompos yang diberikan sama.

\section{Pustaka}

Aganga, A.A. and S.Tshwenyane. 2004. Potentials of guinea grass (Panicum maximum) as forage crop in livestock production. Pakistan Journal of Nutrition, 3: 1-4.

Ferguson, B. J., A. Indrasumunar, S. Hayashi, Meng-Han Lin, Yu-Hsiang Lin, D. E. Reid and P. M. Gresshoff. 2010. Molecular analysis of legume nodule development and autoregulation. Journal of Integrative Plant Biology. 52 (1): $61-76$

Hasibuan, B, E. 2006. Pupuk dan Pemupukan. Fakultas Pertanian Universitas Sumatera Utara. Medan.

Kartini, N. L. 2000. Pertanian organik sebagai pertanian masa depan. Dalam I.N. Rista et al., (Eds). Prosiding Seminar Nasional Pengembangan Teknologi Pertanian dalam Upaya Mendukung Ketahanan Pangan Nasional. IPPTP Denpasar. Badan Litbang Pertanian. Denpasar. hlm.98 105 .

Recycled Organics Unit. 2006. Overview of compost tea use in New South Wales. Recycled Organics Unit, internet publication: www.recycledorganics.com.

Prasetya, B., S. Kurniawan and M. Febrianingsih. 2009. Pengaruh Dosis dan Frekuensi Pupuk Cair Terhadap Serapan N dan Pertumbuhan Sawi (Brassica juncea. L) Pada Entisol. J.Agritek. 17 (5): 1022-1029.

Prasetya, M.E. 2014. PengaruhPupuk NPK Mutiara dan Pupuk Kandang Sapi Terhadap Pertumbuhan dan Hasil Tanaman Cabai Merah Keriting Varietas Arimbi (Capsicum annuum L.), Jurnal Agrifor, 13 (2).

Purbajanti, E. D. 2013. Rumput dan Legum Sebagai Hijauan makanan Ternak Graha Ilmu.Yogyakarta.

Sajimin, I. P. Kompiang, Supriyatidan N. P. Suratmini.2001. Penggunaan Biofertilizer untuk Penigkatan Produktifitas Hijauan Pakan Rumput Gajah (Pennisetum purpureum cv. Afrika) pada Lahan Marjinal di Subang Jawa Barat. Media Peternakan, 24 (2): 46 - 50.

Sajimin, E. Sutedi, B.R.Prawiradiputra, N.D.Purwantari, S. Yuhaeni, A.Semali. I. Herdiawan dan A. Fanindi. 2004. Pemanfaatan plasma nutfah tanaman PakanTernak melalui uji palatabilitas. Laporan kegiatan penelitian T.A. 2004. Balitnak.

Suwarno dan K. Idris. 2007. Potensi dan Kemungkinan Penggunaan Guano SecaraLangsung Sebagai Pupuk Di Indonesia. Jurnal Tanah dan Lingkungan, 9 (1) : 37-43.

Wiryanta. W dan Bernardinus. T. 2002. Bertanam Cabai Pada Musim Hujan Agromedia Pustaka. Jakarta. 